\title{
A Note on the Computation of the Equity Premium and the Market Value of Firm Equity
}

\author{
Burkhard Heer \\ Alfred Maussner
}

CESIFO WORKING PAPER No. 3042

CATEGory 6: Fiscal Policy, MACROECONOMICS AND GROWTH

APRIL 2010

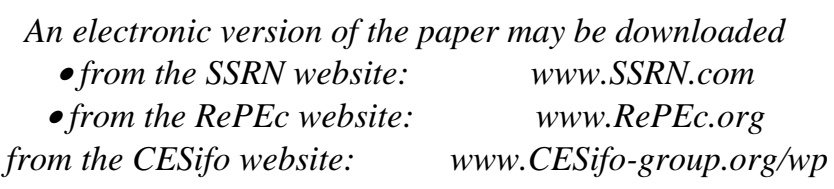




\title{
A Note on the Computation of the Equity Premium and the Market Value of Firm Equity
}

\begin{abstract}
Turnovsky (1995) derives in a continuous-time model of a decentralized economy that the correct specification of the firm's objective function is to maximize the initial value of its outstanding securities. The firm value is the discounted flow of real earnings. For the discretetime version of the model, we show that the correct computation of the firm value needs to be modified. Depending on the specific formula employed, different values of the equity premium result.
\end{abstract}

JEL-Code: G12, C63, E22, E32.

Keywords: asset prices, firm value, equity premium.

Burkhard Heer

Free University of Bolzano-Bozen

School of Economics and Management

1 via Sernesi

39100 Bolzano-Bozen

Italy

Burkhard.Heer@unibz.it
Alfred Maussner

University of Augsburg

Department of Economics

Universitätsstrasse 16

86159 Augsburg

Germany

alfred.maussner@wiwi.uni-augsburg.de

This version: April 28, 2010

We would like to thank Stephen Turnovsky for his helpful comments. All remaining errors are ours. 


\section{Introduction}

Asset pricing in production economies has been extensively studied in the literature, e.g. in Jerman (1998). In these models, the asset value of the firm $\tilde{V}_{t}$ in period $t$ is typically computed as the expected discounted sum of future cash flows: ${ }^{1}$

$$
\tilde{V}_{0}=\mathbb{E}_{0} \sum_{t=0}^{\infty} \beta^{t} \frac{\lambda_{t}}{\lambda_{0}} C F_{t},
$$

where $\beta, \lambda_{t}$, and $C F_{t}$ denote the discount factor of the household, the marginal utility of consumption, and the cash flow in period $t$. The operator $\mathbb{E}_{0}$ denotes mathematical expectations with respect to information as of period 0 .

We instead derive the firm value as:

$$
V_{0}=\mathbb{E}_{0} \sum_{t=0}^{\infty} \beta^{t+1} \frac{\lambda_{t}}{\lambda_{-1}} C F_{t} .
$$

In the following, we will briefly describe the model of Jermann (1998) that is often used as a benchmark for the computation of asset prices and solve it for the firm value. ${ }^{2}$ In addition, we show that the value of the equity premium depends on the specification of the firm value.

\section{The Economy}

We consider the asset pricing model of Jerman (1998) and follow the description of this model in Herr and Maußner (2009). The set-up is the standard real business cycle model with a household and production sector. Productivity is subject to a random shock. There is a single good that is used in investment and consumption. Time is discrete and denoted by $t$.

\footnotetext{
${ }^{1}$ For example, see equation (2.1) of Jermann (1998).

${ }^{2}$ We could have also derived these results in a much simpler version of a production economy without habit formation and adjustment cost of capital. We, however, have chosen the more complex model as it features so prominently in the asset pricing literature, e.g. in Boldrin et al. (2001) or Lettau and Uhlig (2000).
} 


\subsection{Households}

A representative household supplies labor in a fixed amount of $N=1$ at the real wage $w_{t}$. Besides labor income he receives dividends $d_{t}$ per unit of share $S_{t}$ he holds of the representative firm. The current price of shares in units of the consumption good is $v_{t}$. His current period utility function $u($.$) depends on current and past consumption, C_{t}$ and $C_{t-1}$, respectively. Given his initial stock of shares $S_{t}$ the households maximizes

$$
\mathbb{E}_{t} \sum_{s=0}^{\infty} \beta^{s}\left\{\frac{\left(C_{t+s}-b C_{t+s-1}\right)^{1-\eta}-1}{1-\eta}\right\}, \quad \eta \geq 0, \beta \in(0,1)
$$

subject to the sequence of budget constraints

$$
v_{t}\left(S_{t+1}-S_{t}\right) \leq w_{t}+d_{t} S_{t}-C_{t}
$$

The first-order conditions of this problem are:

$$
\begin{aligned}
\lambda_{t} & =\left(C_{t}-b C_{t-1}\right)^{-\eta}-\beta b \mathbb{E}_{t}\left(C_{t+1}-b C_{t}\right)^{-\eta} \\
\lambda_{t} & =\beta \mathbb{E}_{t} \lambda_{t+1} R_{t+1} \\
R_{t} & :=\frac{d_{t}+v_{t}}{v_{t-1}}
\end{aligned}
$$

where $\lambda_{t}$ is the Lagrange multiplier of the budget constraint and $R_{t}$ denotes the current period gross return on equity.

\section{$2.2 \quad$ Firms}

The representative firm uses labor $N_{t}$ and capital $K_{t}$ to produce output $Y_{t}$ according to the production function

$$
Y_{t}=Z_{t} N_{t}^{1-\alpha} K_{t}^{\alpha}, \quad \alpha \in(0,1)
$$

The level of total factor productivity $Z_{t}$ is governed by the AR(1)-Process

$$
\ln Z_{t}=\rho^{Z} \ln Z_{t-1}+\epsilon_{t}^{Z}, \quad \epsilon_{t}^{Z} \sim N\left(0,\left(\sigma^{Z}\right)^{2}\right) .
$$

The firm finances part of its investment $I_{t}$ from retained earnings $R E_{t}$ and issues new shares to cover the remaining part:

$$
I_{t}=v_{t}\left(S_{t+1}-S_{t}\right)+R E_{t} .
$$


It distributes the excess of its profits over retained earnings to the household sector:

$$
d_{t} S_{t}=Y_{t}-w_{t} N_{t}-R E_{t}
$$

Investment increases the firm's future stock of capital according to:

$$
K_{t+1}=\Phi\left(I_{t} / K_{t}\right) K_{t}+(1-\delta) K_{t}, \quad \delta \in[0,1]
$$

where $\delta$ denotes the rate of depreciation and adjustment costs $\Phi($.$) are a positive$ concave function.

\subsection{Computation of the Firm Value}

To derive the objective function of the firm, we follow Turnovsky (1995). Let $V_{t+1}$ denote the value of the shares at the end of period $t, V_{t+1}=v_{t} S_{t+1}$. From (2.5), (2.6), and $(2.2 \mathrm{c})$, we get

$$
\begin{aligned}
V_{t+1} & =v_{t} S_{t+1}=\left(v_{t}+d_{t}\right) S_{t}-\left(Y_{t}-w_{t} N_{t}-I_{t}\right) \\
& =\frac{v_{t}+d_{t}}{v_{t-1}} v_{t-1} S_{t}-C F_{t} \\
& =R_{t} V_{t}-C F_{t}
\end{aligned}
$$

where the cash flow in period $t$ is defined as $C F_{t}=Y_{t}-w_{t} N_{t}-I_{t}$. Iteration of these equation yields (1.2):

$$
V_{0}=\mathbb{E}_{0} \sum_{t=0}^{\infty} \beta^{t+1} \frac{\lambda_{t}}{\lambda_{-1}} C F_{t} .
$$

\subsection{Optimality Conditions of the Firm}

The firm's objective is to maximize $V_{0}$ given in (2.8) subject to the constraint (2.7). The first-order conditions of the firm are: ${ }^{3}$

$$
\begin{aligned}
w_{t} & =(1-\alpha) Z_{t} N_{t}^{-\alpha} K_{t}^{\alpha} \\
q_{t} & =\frac{1}{\Phi^{\prime}\left(I_{t} / K_{t}\right)} \\
q_{t} & =\mathbb{E}_{t} \beta \frac{\lambda_{t+1}}{\lambda_{t}}\left\{\alpha Z_{t+1} N_{t+1}^{1-\alpha} K_{t+1}^{\alpha-1}-\left(I_{t+1} / K_{t+1}\right)+q_{t+1}\left[\Phi\left(I_{t+1} / K_{t+1}\right)+1-\delta\right]\right\}
\end{aligned}
$$

\footnotetext{
${ }^{3}$ Note that the same set of conditions derives from maximizing (1.1).
} 
In addition, the transversality condition

$$
\lim _{t \rightarrow \infty} \mathbb{E}_{0} \beta^{t+1} \frac{\Lambda_{t}}{\Lambda_{-1}} q_{t} K_{t+1}=0
$$

must hold.

\section{Computation of the Asset Prices}

In order to illustrate the implications of the firm value specification for asset pricing, we consider a numerical example. We will first describe our calibration procedure before we present our details for the computation of the equity premium.

\subsection{Calibration}

Periods correspond to quarters. We parameterize the function $\Phi$ from (2.7) as

$$
\Phi\left(I_{t} / K_{t}\right):=\frac{a_{1}}{1-\zeta}\left(\frac{I_{t}}{K_{t}}\right)^{1-\zeta}+a_{2}, \quad \zeta>0 .
$$

The choice of the parameters $a_{1}$ and $a_{2}$ is described in the Appendix. For the remaining parameters, we use values that are standard in the literature. In particular, we follow Heer and Maußner (2009), Section 6.3.4. Table 3.1 displays the respective values. The discount factor $\beta$ is set equal to 0.994 implying an annual risk free rate in the stationary equilibrium of $2.4 \%$.

Table 3.1

Benchmark calibration

\begin{tabular}{lllll}
\hline \hline Preferences & $\beta=0.994$ & $b=0.8$ & $\eta=2$ & \\
Production & $\alpha=0.27$ & $\delta=0.011$ & $\rho^{Z}=0.90$ & $\sigma^{Z}=0.0072$ \\
& $\zeta=1 / 0.23$ & & & \\
\hline
\end{tabular}

The solution of the model are functions $g^{i}, i \in\{K, Y, C, I, \lambda, q\}$, that determine $K_{t+1}$, $Y_{t}, C_{t}, I_{t}, \lambda_{t}$, and $q_{t}$ given the current period state variables $K_{t}, C_{t-1}$, and the log of the productivity shock $\ln Z_{t}$. We use the quadratic approximation of $g^{\lambda}$ at the stationary equilibrium which is derived in the Appendix. ${ }^{4}$

\footnotetext{
${ }^{4}$ The source code is available in the Fortran program Model_Equity_2.for and can be downloaded from Alfred Maußner's homepage 'http://www.wiwi.uni-augsburg.de/vwl/maussner/'.
} 


\subsection{Asset Price Implications}

In the following, we derive the risk-free rate of return and three different expressions for the return on equity, $R_{t}^{e_{1}}, R_{t}^{e_{2}}$, and $R_{t}^{e_{3}}$.

In our model the risk free rate of return $r_{t}$ is given by

$$
r_{t}=\frac{\lambda_{t}}{\beta \mathbb{E}_{t} \lambda_{t+1}}-1
$$

Since

$$
\begin{aligned}
\lambda_{t+1} & =g^{\lambda}\left(K_{t+1}, C_{t}, \ln Z_{t+1}\right) \\
& =g^{\lambda}\left(g^{K}\left(K_{t}, C_{t-1}, \ln Z_{t}\right), g^{C}\left(K_{t}, C_{t-1}, \ln Z_{t}\right), \varrho \ln Z_{t}+\epsilon_{t+1}^{Z}\right) \\
& =: \tilde{g}^{\lambda}\left(K_{t}, C_{t-1}, \rho \ln Z_{t}+\epsilon_{t+1}^{Z},\right)
\end{aligned}
$$

and $\epsilon_{t+1}^{Z}$ is normally distributed, the expected value of the Lagrange multiplier equals

$$
\mathbb{E}_{t} \lambda_{t+1}=\int_{-\infty}^{\infty} \tilde{g}^{\lambda}\left(K_{t}, C_{t-1}, \rho \ln Z_{t}+\epsilon_{t+1}^{Z},\right) \frac{1}{\sigma^{Z} \sqrt{2 \pi}} e^{\frac{-\left(\epsilon_{t+1}^{Z}\right)^{2}}{\left(\sigma^{Z}\right)^{2}}} d \epsilon_{t+1}^{Z} .
$$

We use the Gauss-Hermite 6-point quadrature formula to approximate the integral on the right-hand-side of this equation.

The labor market equilibrium condition (2.9a) and equation (2.7) imply that the righthand-side of $(2.9 \mathrm{c})$ can be written as

$$
\begin{aligned}
1 & =\beta \mathbb{E}_{t} \frac{\lambda_{t+1}}{\lambda_{t}} \frac{Y_{t+1}-w_{t+1} N_{t+1}-I_{t+1}+q_{t+2} K_{t+2}}{q_{t} K_{t+1}}, \\
& =\beta \mathbb{E}_{t} \frac{\lambda_{t+1}}{\lambda_{t}} \frac{d_{t+1}+v_{t+1}}{v_{t}}=\beta \mathbb{E}_{t} \frac{\lambda_{t+1}}{\lambda_{t}} R_{t+1}
\end{aligned},
$$

where the second equality follows from equations (2.5) and (2.6) and the observation that $q_{t} K_{t+1}=v_{t} S_{t+1}$ (see Heer and Maußner (2009), p. 317). Therefore, the gross rate of return on the shares of the representative firm equals ${ }^{5}$

$$
R_{t+1}^{e_{1}}=\frac{\alpha Y_{t+1}-I_{t+1}+q_{t+1} K_{t+2}}{q_{t} K_{t+1}} .
$$

Alternatively, we can use the value of the firm as computed by (1.1) and (1.2), respectively, in order to derive an expression for the return on equity. For this reason, we assume that the number of shares is constant and equal to one, $S_{t} \equiv 1$. Consequently,

$$
\begin{aligned}
& R_{t+1}^{e_{2}}=\frac{d_{t}+V_{t+1}}{V_{t}} \\
& R_{t+1}^{e_{3}}=\frac{d_{t}+\tilde{V}_{t+1}}{\tilde{V}_{t}} .
\end{aligned}
$$


Table 3.2

Equity premium

$$
\begin{array}{ll}
\hline \hline \overline{R_{t+1}^{e_{1}}-r_{t}} & 4.00 \% \\
\overline{R_{t+1}^{e_{2}}-r_{t}} & 3.86 \% \\
\overline{R_{t+1}^{e_{3}}-r_{t}} & 3.94 \% \\
\hline
\end{array}
$$

We use a random number generator to compute a long artificial time series for $R_{t+1}^{e_{i}}-r_{t}$, $i=1,2,3$. The averages of these time series are our measures of the ex-post equity premium implied by the model. For a time series of 1,000,000 observations and the parameters from Table 3.1, the results are summarized in 3.2. We find an average annual risk-free rate of about $2.4 \%$ percent and an equity premium of $4.00 \%, 3.86 \%$, and $3.94 \%$ for the three different computations considered in (3.2), (3.3), and (3.4), respectively. ${ }^{6}$

\section{Conclusion}

In this note, we show that the correct firm value is given by (1.2) rather than (1.1). The equity premium that result from the model of the production economy depends on this specification. For our parametric example, we find equity premia in the range of $3.86 \%$ to $4.00 \%$.

\footnotetext{
${ }^{5}$ Note, $\alpha Y_{t+1}=Y_{t+1}-w_{t+1} N_{t+1}$.

${ }^{6}$ In particular, we used the same sequence of shocks and, therefore, the same sequence of state variables for the computation of the three different formulas of the equity premium.
} 


\section{References}

Boldrin, M., L.J. Christiano, and J.D.M. Fisher, 2001, Habit Persistence, Asset Return, and the Business Cycle, American Economic Review, vol. 91, 149-166.

Heer, B., and A. Maussner, 2009, Dynamic General Equilibrium Models: Computation and Applications, 2nd edition, Heidelberg: Springer.

Jermann, U.J., 1998, Asset Pricing in Production Economies. Journal of Monetary Economics, vol. 41, 257-275.

Lettau, M., and H.Uhlig, 2000, Can Habit Formation Be Reconciled with Business Cycle Facts?, Review of Economic Dynamics, vol.3, 79-99.

Turnovsky, S.J., 1995, Methods of Macroeconomic Dynamics, MIT Press: Cambridge, Mass.

\section{Appendix: Deterministic Stationary Equilibrium}

Our solution strategy rests on a second-order approximation of the model. Therefore, we must consider the stationary equilibrium of the deterministic counterpart of our model. To this end, we set $\sigma^{Z}=0$ so that $Z_{t}$ equals its unconditional expectation $Z=1$ for all $t$. Stationarity implies $x_{t+1}=x_{t}=x$ for any variable $x_{t}$ in our model. As usual, we specify $\Phi$ so that adjustment costs play no role in the stationary equilibrium, i.e., $\Phi(I / K) K=\delta K$ and $q=\Phi^{\prime}(\delta)=1$. This requires that we choose

$$
\begin{aligned}
& a_{1}=\delta^{\zeta}, \\
& a_{2}=\frac{-\zeta \delta}{1-\zeta} .
\end{aligned}
$$

These assumptions imply the stationary solution for the stock of capital:

$$
K=\left(\frac{1-\beta(1-\delta)}{\alpha \beta}\right)^{\frac{1}{\alpha-1}}
$$

Output, investment, consumption, and the stationary solution for $\lambda$ are then given by

$$
\begin{aligned}
Y & =K^{\alpha}, \\
I & =\delta K, \\
C & =Y-I,
\end{aligned}
$$




$$
\lambda=C^{-\eta}(1-b)^{-\eta}(1-b \beta) .
$$

In order to determine the firm's value, we use a recursive formulation of (1.1) and (1.2), respectively. In particular, (1.1) gives rise to

$$
\tilde{V}_{t}=C F_{t}+\beta \frac{\Lambda_{t+1}}{\Lambda_{t}} \tilde{V}_{t+1},
$$

whereas (1.2) implies

$$
V_{t}=\beta \frac{\Lambda_{t}}{\Lambda_{t-1}} C F_{t}+\beta \frac{\Lambda_{t}}{\Lambda_{t-1}} V_{t+1} .
$$




\section{CESifo Working Paper Series}

for full list see www.cesifo-group.org/wp

(address: Poschingerstr. 5, 81679 Munich, Germany, office@cesifo.de)

2977 Johann K. Brunner and Susanne Pech, Optimum Taxation of Bequests in a Model with Initial Wealth, March 2010

2978 Guglielmo Maria Caporale and Nicola Spagnolo, Stock Market Integration between three CEECs, Russia and the UK, March 2010

2979 Florian Englmaier, Ales Filipi and Ravi Singh, Incentives, Reputation and the Allocation of Authority, March 2010

2980 Konstantinos Angelopoulos, George Economides and Apostolis Philippopoulos, What is the Best Environmental Policy? Taxes, Permits and Rules under Economic and Environmental Uncertainty, March 2010

2981 Frederick van der Ploeg, Rapacious Resource Depletion, Excessive Investment and Insecure Property Rights, March 2010

2982 Wolfram F. Richter and Christoph Braun, Efficient Subsidization of Human Capital Accumulation with Overlapping Generations and Endogenous Growth, March 2010

2983 Francesco Cinnirella, Marc Piopiunik and Joachim Winter, Why Does Height Matter for Educational Attainment? Evidence from German Pre-Teen Children, March 2010

2984 Bernard Van Praag, Well-being Inequality and Reference Groups - An Agenda for New Research, March 2010

2985 Francesca Barion, Raffaele Miniaci, Paolo M. Panteghini and Maria Laura Parisi, Profit Shifting by Debt Financing in Europe, March 2010

2986 Alexander Haupt and Magdalena Stadejek, The Choice of Environmental Policy Instruments: Energy Efficiency and Redistribution, March 2010

2987 John Komlos and Marek Brabec, The Trend of BMI Values among US Adults, March 2010

2988 Emanuele Massetti and Lea Nicita, The Optimal Climate Policy Portfolio when Knowledge Spills across Sectors, March 2010

2989 Helmut Rainer and Thomas Siedler, Family Location and Caregiving Patterns from an International Perspective, March 2010

2990 Toru Kikuchi and Ngo Van Long, A Simple Model of Service Offshoring with Time Zone Differences, March 2010

2991 Assaf Razin, Efraim Sadka and Benjarong Suwankiri, Migration and the Welfare State: Dynamic Political-Economy Theory, March 2010 
2992 Bård Harstad, Buy Coal! Deposit Markets Prevent Carbon Leakage, March 2010

2993 Axel Dreher, Stephan Klasen, James Raymond Vreeland and Eric Werker, The Costs of Favoritism: Is Politically-driven Aid less Effective?, March 2010

2994 Sven Neelsen and Thomas Stratmann, Effects of Prenatal and Early Life Malnutrition: Evidence from the Greek Famine, March 2010

2995 Claude Hillinger and Bernd Süssmuth, The Quantity Theory of Money: An Assessment of its Real Linchpin Prediction, March 2010

2996 Matthew M. Chingos and Martin R. West, Do More Effective Teachers Earn More Outside of the Classroom?, March 2010

2997 Laurence Jacquet and Dirk Van de gaer, A Comparison of Optimal Tax Policies when Compensation or Responsibility Matter, March 2010

2998 Valentina Bosetti, Carlo Carraro, Romain Duval and Massimo Tavoni, What Should we Expect from Innovation? A Model-Based Assessment of the Environmental and Mitigation Cost Implications of Climate-Related R\&D, March 2010

2999 Scott Alan Carson, Nineteenth Century Stature and Family Size: Binding Constraint or Productive Labor Force?, March 2010

3000 Jukka Pirttilä and Ilpo Suoniemi, Public Provision, Commodity Demand and Hours of Work: An Empirical Analysis, March 2010

3001 Bertrand Candelon and Franz C. Palm, Banking and Debt Crises in Europe: The Dangerous Liaisons?, March 2010

3002 Joan Costa-i-Font and Marin Gemmill-Toyama, Does Cost Sharing really Reduce Inappropriate Prescriptions?, March 2010

3003 Scott Barrett, Climate Treaties and Backstop Technologies, March 2010

3004 Hans Jarle Kind, Tore Nilssen and Lars Sørgard, Price Coordination in Two-Sided Markets: Competition in the TV Industry, March 2010

3005 Jay Pil Choi and Heiko Gerlach, Global Cartels, Leniency Programs and International Antitrust Cooperation, March 2010

3006 Aneta Hryckiewicz and Oskar Kowalewski, Why do Foreign Banks Withdraw from other Countries? A Panel Data Analysis, March 2010

3007 Eric A. Hanushek and Ludger Woessmann, Sample Selectivity and the Validity of International Student Achievement Tests in Economic Research, March 2010

3008 Dennis Novy, International Trade and Monopolistic Competition without CES: Estimating Translog Gravity, April 2010 
3009 Yin-Wong Cheung, Guonan Ma and Robert N. McCauley, Renminbising China's Foreign Assets, April 2010

3010 Michel Beine and Sara Salomone, Migration and Networks: Does Education Matter more than Gender?, April 2010

3011 Friedrich Schneider, Tilman Brück and Daniel Meierrieks, The Economics of Terrorism and Counter-Terrorism: A Survey (Part I), April 2010

3012 Friedrich Schneider, Tilman Brück and Daniel Meierrieks, The Economics of Terrorism and Counter-Terrorism: A Survey (Part II), April 2010

3013 Frederick van der Ploeg and Steven Poelhekke, The Pungent Smell of "Red Herrings": Subsoil Assets, Rents, Volatility and the Resource Curse, April 2010

3014 Vjollca Sadiraj, Jan Tuinstra and Frans van Winden, Identification of Voters with Interest Groups Improves the Electoral Chances of the Challenger, April 2010

3015 Guglielmo Maria Caporale, Davide Ciferri and Alessandro Girardi, Time-Varying Spot and Futures Oil Price Dynamics, April 2010

3016 Scott Alan Carson, Racial Differences in Body-Mass Indices for Men Imprisoned in $19^{\text {th }}$ Century US Prisons: A Multinomial Approach, April 2010

3017 Alessandro Fedele, Paolo M. Panteghini and Sergio Vergalli, Optimal Investment and Financial Strategies under Tax Rate Uncertainty, April 2010

3018 Laurence Jacquet, Take it or Leave it: Take-up, Optimal Transfer Programs, and Monitoring, April 2010

3019 Wilhelm Kohler and Jens Wrona, Offshoring Tasks, yet Creating Jobs?, April 2010

3020 Paul De Grauwe, Top-Down versus Bottom-Up Macroeconomics, April 2010

3021 Karl Ove Aarbu, Demand Patterns for Treatment Insurance in Norway, April 2010

3022 Toke S. Aidt and Jayasri Dutta, Fiscal Federalism and Electoral Accountability, April 2010

3023 Bahram Pesaran and M. Hashem Pesaran, Conditional Volatility and Correlations of Weekly Returns and the VaR Analysis of 2008 Stock Market Crash, April 2010

3024 Stefan Buehler and Dennis L. Gärtner, Making Sense of Non-Binding Retail-Price Recommendations, April 2010

3025 Leonid V. Azarnert, Immigration, Fertility, and Human Capital: A Model of Economic Decline of the West, April 2010

3026 Christian Bayer and Klaus Wälde, Matching and Saving in Continuous Time: Theory and 3026-A Matching and Saving in Continuous Time: Proofs, April 2010 
3027 Coen N. Teulings and Nick Zubanov, Is Economic Recovery a Myth? Robust Estimation of Impulse Responses, April 2010

3028 Clara Graziano and Annalisa Luporini, Optimal Delegation when the Large Shareholder has Multiple Tasks, April 2010

3029 Erik Snowberg and Justin Wolfers, Explaining the Favorite-Longshot Bias: Is it RiskLove or Misperceptions?, April 2010

3030 Doina Radulescu, The Effects of a Bonus Tax on Manager Compensation and Welfare, April 2010

3031 Helmut Lütkepohl, Forecasting Nonlinear Aggregates and Aggregates with Timevarying Weights, April 2010

3032 Silvia Rocha-Akis and Ronnie Schöb, Welfare Policy in the Presence of Unionised Labour and Internationally Mobile Firms, April 2010

3033 Steven Brakman, Robert Inklaar and Charles van Marrewijk, Structural Change in OECD Comparative Advantage, April 2010

3034 Dirk Schindler and Guttorm Schjelderup, Multinationals, Minority Ownership and TaxEfficient Financing Structures, April 2010

3035 Christian Lessmann and Gunther Markwardt, Decentralization and Foreign Aid Effectiveness: Do Aid Modality and Federal Design Matter in Poverty Alleviation?, April 2010

3036 Eva Deuchert and Conny Wunsch, Evaluating Nationwide Health Interventions when Standard Before-After Doesn't Work: Malawi's ITN Distribution Program, April 2010

3037 Eric A. Hanushek and Ludger Woessmann, The Economics of International Differences in Educational Achievement, April 2010

3038 Frederick van der Ploeg, Aggressive Oil Extraction and Precautionary Saving: Coping with Volatility, April 2010

3039 Ainura Uzagalieva, Evžen Kočenda and Antonio Menezes, Technological Imitation and Innovation in New European Union Markets, April 2010

3040 Nicolas Sauter, Jan Walliser and Joachim Winter, Tax Incentives, Bequest Motives, and the Demand for Life Insurance: Evidence from two Natural Experiments in Germany, April 2010

3041 Matthias Wrede, Multinational Capital Structure and Tax Competition, April 2010

3042 Burkhard Heer and Alfred Maussner, A Note on the Computation of the Equity Premium and the Market Value of Firm Equity, April 2010 